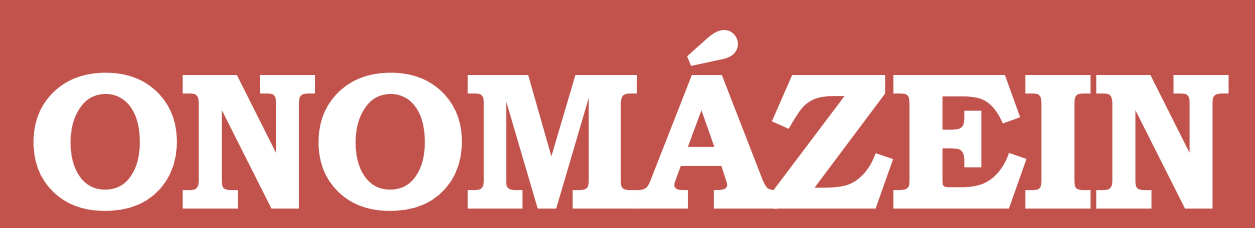

Revista de lingüística, filología y traducción
PONTIFICIA UNIVERSIDAD CATÓLICA DE CHILE FACULTAD DE LETRAS

\title{
La recepción de Henri-René Lenormand en la España de principios de siglo $\mathbf{X X}^{\mathbf{1}}$
}

Henri-René Lenormand's reception in the early twentieth century Spain

\section{David Marín Hernández}

Universidad de Málaga

España

\section{(C) $($ ii) $\ominus$}

David Marín Hernández: Departamento de Traducción e Interpretación, Facultad de Filosofía y Letras, Universidad de Málaga, España. | Correo electrónico: dmarin@uma.es 


\section{Resumen}

Pese a que actualmente apenas es leído o representado en los teatros, Lenormand fue uno de los autores vanguardistas que más interés generó a principios de siglo XX. La acogida que el público español brindó al autor francés fue especialmente calurosa. Sus obras se traducían y representaban con frecuencia, y suscitaban intensos debates en las revistas literarias. Sin embargo, la concepción psicológica del ser humano que Lenormand ofrecía en sus dramas dividió en dos a la crítica española: aquellos que defendían sus propuestas freudianas y aquellos otros sectores más conservadores que rechazaron las novedades lenormandianas por no encajar en las tendencias teatrales que imperaban en la España de principios de siglo XX. Otro de los aspectos controvertidos en la recepción española de Lenormand fue el supuesto carácter innovador de su teatro: ¿era realmente un autor vanguardista o se limitaba a trasladar al siglo XX los grandes dramas del teatro clásico? En este trabajo estudiaremos las diversas reacciones que la obra de Lenormand suscitó entre los críticos españoles de principios de siglo XX.

Palabras clave: Lenormand; teatro vanguardista; recepción literaria; traducción literaria; revistas literarias.

\section{Abstract}

Even if Lenormand's works are barely read or played in actual days, he was one of the avant-garde authors that generated more attention in the early twentieth century. The French author was enthusiastically welcomed by Spanish public. His works were frequently translated and played in Spanish theaters and intense debates were hold in literary reviews about how to interpret his characters. However, Lenormand's psychological conception of human being divided Spanish criticism in two groups: those who were in favour of his freudian proposals and those conservative critics who rejected Lenormand's novelties because they did not fit in the theatrical trends prevailing in early twentieth century Spain. Another controversial

1 Este trabajo se enmarca en el Proyecto I+D+i «Traducción y recepción de la literatura extranjera en las revistas literarias españolas (1900-1939)»(HUM2007-66776/FILO), financiado por el Ministerio de Educación y Ciencia. 
aspect in the Spanish reception of Lenormand's works was the alleged innovative nature of his theater: was he really an avant-garde author or did he merely relocate the great dramas of classical theater into the twentieth century? The aim of this paper is to study the diverse reactions stimulated by Lenormand's works among Spanish criticism.

Keywords: Lenormand; avant-garde theatre; literary reception; literary translation; literary reviews. 


\section{Introducción}

Uno de los autores vanguardistas que más resonancia adquirió en el panorama teatral europeo de los años veinte fue el dramaturgo francés Henri-René Lenormand (Blanchart, 1947; Morrison, 1972). Prácticamente olvidado en el siglo XXI, apenas leído o representado actualmente (Kaczmarek, 2008)², Henri-René Lenormand fue, sin embargo, uno de los escritores más célebres y aplaudidos en los escenarios europeos del periodo de entreguerras. Sus obras eran codiciadas por los mejores directores del momento (Georges Pitoëff, Louis Jouvet, Max Reinhard, Gaston Baty, Charles Dullin, Margarita Xirgu, Rivas Cherif) y se representaban en las grandes capitales europeas y americanas (estrenó en París, Londres, Madrid, Barcelona, Viena, Berlín, Ámsterdam, Varsovia, Nueva York, etc.) (Vilches de Frutos y Dogherty, 1997). A diferencia de otros dramaturgos vanguardistas, Lenormand no tuvo que luchar para ver sus dramas en los teatros: Ios empresarios de la época — tan reacios, en general, a apostar por cualquier novedad que se saliese de los caminos ya trillados del teatro comercial- luchaban por estrenar las obras de Lenormand, seguros de obtener un éxito de público.

Este éxito se explica no solo por la calidad literaria de sus obras, sino también por su capacidad para reflejar la angustia existencial que se apoderó de Europa a principios de siglo XX (Kaczmarek, 2004). La profunda crisis de valores que se vivió en Occidente al comienzo del siglo generó también una crisis del individuo moderno, quien se sintió desamparado ante el sinsentido trágico de la vida³. La tragedia ya no venía impuesta por fuerzas exteriores —los

2 Entre las razones que proponen los críticos para explicar su pérdida de popularidad a partir de la Segunda Guerra Mundial se ha señalado, por un lado, la falta de sintonía con el público, al que molestaban tanto los diálogos excesivamente "intelectualizados" como los temas mórbidos que se plantean en muchas de sus obras; se ha denunciado también la política editorial de la Francia de posguerra, ya que se dejaron de publicar los dramas de Lenormand por considerar que los planteamientos morales del autor habían perdido vigencia (Winnett, 1996). No puede descartarse que la tibieza del escritor ante las tropas de ocupación alemanas durante la guerra contribuyera igualmente al olvido del dramaturgo en su país natal (Carat, 1949). En cualquier caso, han de señalarse también diversos intentos en los últimos años por recuperar la obra de Lenormand, no solo desde el ámbito académico, sino también en los escenarios. Jean-Louis Benoit, director del Teatro Nacional de Marsella, montó en 1995 Les Ratés, y más recientemente, en 2008, se ha encargado del montaje de Le Temps est un songe.

3 En la Revista de Occidente - que, como se verá en las siguientes páginas, contribuyó decisivamente a la difusión de Lenormand en España - escribía Ortega y Gasset en el número de julio de 1923 acerca de esta crisis de valores: "Muchas gentes comienzan a sentir la penosa impresión de ver su existencia invadida por el caos". Ante este panorama, no es de extrañar que las filosofías irracionalistas adquiriesen una vigencia social extraordinaria (Fusi, 2003). Los propios testimonios de Lenormand dejan constancia de su reacción personal ante este "malaise dans le monde" (Lenormand, 1953: 12). 
dioses del mundo clásico que manipulaban a los mortales como marionetas-, sino por impulsos interiores del inconsciente, ante los cuales el ser humano se sentía aún más desconcertado. Los personajes de Lenormand padecían la dolorosa inquietud de quien se siente movido por engranajes internos cuyo funcionamiento desconoce. Las escenas de sus obras nos presentan individuos desorientados ante una identidad fragmentada cuyo misterio se esfuerzan en vano por comprender. La popularidad de la que gozó el dramaturgo galo en toda Europa se debió fundamentalmente a su habilidad para darle forma artística a este malestar vital que atenazó al continente.

España fue uno de los países que mejor acogida le brindó al autor francés, tanto en lo personal como en lo literario. La atención con la que los intelectuales españoles de principios de siglo XX seguían la literatura europea - especialmente la francesa- permitió que la notoriedad de Lenormand Ilegase rápidamente a España, donde su obra no solo se traducía y representaba (Martín Rodríguez, 1992, 1994; Vilches de Frutos y Dogherty, 1997), sino que suscitaba interesantes debates en las revistas literarias. Los lectores españoles no necesitaron esperar a que sus obras se tradujesen o representasen en España para conocerlo, ya que los corresponsales de los diarios y revistas literarias informaban puntualmente de las representaciones de sus dramas en Francia —un nuevo ejemplo de que la traducción no siempre inaugura la recepción de un autor extranjero-. Pocos meses después de que L'Homme et ses fantômes se estrenase en el teatro parisino Odéon en junio de 1924, apareció en el diario español Heraldo de Madrid una crónica del estreno en la que, junto con un retrato del dramaturgo francés y unos dibujos de algunas escenas, se resumía el argumento de la obra y se ofrecía una primera interpretación acerca de los interrogantes psicológicos que planteaba Lenormand.

La vinculación entre traducción y crítica literaria resulta palmaria en el caso de L'Homme et ses fantômes, pues ambas facetas del proceso de recepción se aunaron en la misma persona: Enrique Díez-Canedo fue no solo uno de los críticos que más defendió la nueva estética lenormandiana a través de artículos en revistas literarias, sino que se encargó también de traducir esta obra.

No solo su obra fue objeto de una buena recepción: también el escritor en persona fue acogido calurosamente por críticos y espectadores. Lenormand era invitado con frecuencia a asistir al estreno de sus obras, y en más de una ocasión acudió a España para impartir conferencias sobre el teatro europeo (en la Residencia de Estudiantes) o sobre su propia obra (Margarita Xirgu lo invitó al estreno de Los fracasados en Madrid para que explicase su concepción del teatro, y también viajó a Barcelona para presentar el estreno de esta obra en catalán, Els fracassats, en traducción de Pous y Pagés y Soldevila) (La Esfera, 27 de octubre de 1928).

La vinculación de Lenormand con España no fue solo literaria. En una nota publicada en el $A B C$ del 24 de mayo de 1936 se da cuenta de la participación de Lenormand junto con 
André Malraux y Jean Cassous en unas jornadas celebradas en el Ateneo de Madrid (Cremades Gómez-Pablos, 2003). La crónica lleva un significativo título que pretende subrayar la verdadera naturaleza de este viaje: "Viaje político de unos literatos franceses" (cursivas nuestras). En efecto, el motivo de esta conferencia era proponer la creación en España de una asociación de escritores y artistas que se comprometiesen activamente en la propaganda política del Frente Popular. Además de implicarse en las disputas políticas prebélicas, una vez que estalló la Guerra Civil Lenormand apoyó junto con otros escritores e intelectuales franceses la causa republicana.

Puede decirse, por todo ello, que la figura del dramaturgo francés se integró rápidamente en el panorama intelectual de la España de principios de siglo XX - el propio escritor contaba en una de las muchas entrevistas que concedió a la prensa española la sorpresa que le causó ser reconocido en una ocasión cuando paseaba por Madrid-. Una vez que Lenormand se incorporó al sistema literario español, su obra participó en las discusiones más candentes que animaban la vida cultural de la época. En las siguientes páginas se analizará de qué manera contribuyó la obra lenormandiana a enriquecer uno de los debates que más inspiró a los escritores españoles durante aquellos años: las raíces del mito de Don Juan, entendido este no solo como uno de los arquetipos que las letras españolas habían exportado a la literatura universal, sino también como la ilustración de un trastorno que podía estudiarse tanto desde una perspectiva biológica como psicoanalítica.

También se describirá en este trabajo la división que generaron los dramas de Lenormand entre los críticos españoles: mientras que algunos los recibieron como un soplo de aire fresco que contribuía a renovar el teatro de la época, desde los sectores más conservadores, por el contrario, fueron tachados de perniciosos para la moral pública, pues mostraban la faceta más oscura y depravada del ser humano. Lenormand, en efecto, no dudó en escenificar sobre los escenarios "la secreta connivencia del hombre con las fuerzas que lo destruyen", lo cual atentaba, según ciertos críticos, contra los valores tradicionales que debía transmitir el teatro para cohesionar la sociedad española.

\section{Henri-René Lenormand en la Revista de Occidente: el mito de Don Juan}

Prueba del caluroso recibimiento de que fue objeto el escritor galo por parte de los intelectuales españoles fue la especial atención que se le prestó en una de las revistas culturales más prestigiosas del país, la Revista de Occidente, que no solo le dedicó diversos estudios críticos, sino que llegó incluso a publicar la traducción completa de una de sus obras: la mencionada L'Homme et ses fantômes. La vocación internacional de Ortega y Gasset — fundador y director de la $R O$ - se trasladó a las páginas de una revista que aspiraba a "presentar a sus lectores el panorama esencial de la vida europea y americana" (cursivas nuestras), tal como se 
señaló expresamente en los "Propósitos" publicados en el primer número4. Dado el carácter cosmopolita de esta revista, se comprende fácilmente el elevado número de traducciones que se publicaban en sus páginas. Resulta difícil encontrar algún número en el que no se ofreciese la traducción de algún fragmento literario, ensayístico o científico ${ }^{5}$.

Es cierto que, en comparación con otros géneros literarios, el teatro no ocupó un lugar preponderante en la $R O$, pero tanto las obras dramáticas ${ }^{6}$ como los artículos teóricos sobre dramaturgia’ publicados en sus páginas reflejan claramente una apuesta decidida por el teatro vanguardista y la superación de las obras comerciales que monopolizaban las salas a principios de siglo XX. Frente a las reticencias de muchos empresarios teatrales a la hora de estrenar aquellas obras que, por su novedad, implicaban un riesgo comercial, las revistas literarias de la época - menos sujetas al imperativo de la rentabilidad económica inmediata- se mostraron especialmente receptivas a las tendencias renovadoras (Vilches de Frutos y Dogherty, 1997; sobre la vinculación entre las vanguardias y el periodismo véase igualmente Arizmendi y López, 1997). No es de sorprender, pues, que la figura de Lenormand, claramente asociada al teatro vanguardista, interesase a los responsables de la $R O$, una publicación siempre atenta a las novedades literarias europeas para difundirlas entre los lectores españoles. En 1927, concretamente en los números 49, 50 y 51, se publicó de forma íntegra la traducción de L'Homme et ses fantômes realizada por Enrique Díez-Canedo, uno de los críticos y traduc-

4 Esta inclinación internacional resulta especialmente visible si se compara la $R O$ con otras revistas españolas de la época. Incluso aquellas otras publicaciones que siguieron de cerca la cultura europea, como La Pluma, no alcanzan ni el número de ensayos extranjeros publicados por la revista de Ortega y Gasset ni el discernimiento que este mostró en la selección de trabajos. Es significativo, en este sentido, que ya en 1932 Giménez Caballero distinguiese entre los intelectuales "europeizantes" (entre quienes incluía a Azaña, director de la mencionada La Pluma junto con Rivas Cherif) y los intelectuales verdaderamente "europeizados" (grupo este en el que encuadraba a Ortega) (Bécarud, 1972).

5 Pese a la importancia que los textos traducidos desempeñaron en la $R O$, no puede decirse, sin embargo, que la traducción como actividad profesional e intelectual recibiese el debido reconocimiento por parte de los responsables de la revista. Rara vez, por ejemplo, aparecía mencionado el nombre del traductor, y ello pese a que con frecuencia los encargados de verter en español los textos extranjeros eran escritores y críticos de prestigio. En el mejor de los casos, se le indicaba al lector que el texto que acababa de leer era una traducción y se le ofrecían las iniciales del traductor, "Io que demuestra que este ocultamiento nada tenía que ver con un mayor o menor reconocimiento a la persona del traductor, sino con el escaso o nulo peso simbólico de la traducción en tanto que forma de escritura" (Marín, 2013: 1195).

6 Entre 1923 y 1936 se publicaron obras o fragmentos de obras de nueve dramaturgos: Jean Cocteau, Jean Giraudoux, Henri-René Lenormand, Ferdinand Brückner, Georg Kaiser, Eugene O’Neill, Victoria Ocampo, Ramón Gómez de la Serna y Ricardo Baroja.

7 Se publicaron artículos de Ricardo Baeza (en enero y en junio de 1924), de Dobrée Bonamy (en abril y mayo de 1929), de Antonio Espina (en diciembre de 1925). 
tores más prestigiosos del momento (Marín, 2011), que acompañó su versión con un estudio introductorio sobre el dramaturgo galo. Las obras de Lenormand -elogiadas por sus innovaciones dramatúrgicas y por proponer un lenguaje teatral muy cercano al del moderno cinematógrafo- presentaban muchos de los ingredientes por los que apostaba la RO: renovación literaria, una nueva explicación del ser humano desde nuevos presupuestos psicoanalíticos y una estrecha vinculación entre los rasgos del hombre contemporáneo y las nuevas circunstancias sociales y políticas en las que este vivía.

En efecto, existía una fuerte afinidad entre Lenormand y la concepción humanística de la $R O$, ya que en sus dramas el autor galo plasmaba literariamente la aspiración filosófica de Ortega y Gasset de describir al hombre y sus circunstancias. El propio dramaturgo francés formuló esta aspiración explícitamente, cuando afirmó que su objetivo era reflejar "la double inquiétude qui nous hante, celle de l'homme qui devient et celle du monde qui devient" (Lenormand, 1925); una afirmación que nos recuerda el famoso lema orteguiano, expuesto unos años antes en Meditaciones del Quijote: "Yo soy yo y mi circunstancia, y si no la salvo a ella no me salvo yo" (Ortega y Gasset, 1990 [1914]: 68). Esta sintonía entre Lenormand y Ortega ha de contextualizarse en el ambiente filosófico de la Europa de principios de siglo XX, en el que una nueva generación de pensadores trataba de superar el idealismo decimonónico en aras de propiciar un reencuentro del hombre con el mundo real: "El hombre rinde el máximum de su capacidad cuando adquiere la plena consciencia de sus circunstancias. Por ellas comunica con el universo. iLa circunstancia! Circum -stantia! [...] No detenernos perpetuamente en éxtasis ante los valores hieráticos, sino conquistar a nuestra vida individual el puesto oportuno entre ellos. En suma: la reabsorción de la circunstancia es el destino concreto del hombre” (op. cit., 56).

Este interés que mostró Lenormand hacia los nuevos paradigmas científicos del siglo XX se observa igualmente en la moderna concepción del tiempo de la que hace gala en sus dramas. L'Homme et ses fantômes ilustra perfectamente el abandono de las reglas espaciotemporales aristotélicas y la asunción de las nuevas corrientes relativistas (Kaczmarek, 2010). Lenormand se aleja del realismo imperante en los teatros comerciales de España y apuesta por representar sobre las tablas un mundo onírico que reproduzca los vaivenes espirituales del hombre contemporáneo. La influencia de Strindberg resulta, en este sentido, patente (Gravier, 1971; Kaczmarek, 2015). Los tradicionales actos se dividen en cuadros inconexos (las famosas escenas breves que Lenormand puso de moda), con las cuales trataba de reflejar la rápida sucesión de situaciones y estados de ánimo característica de los sueños, regidos por los impulsos del inconsciente. El clásico planteamiento-nudo-desenlace se quiebra, pues las acciones no se anudan siguiendo criterios racionales: la obra ya no trata de mimetizar una realidad que ha dejado de ser vista como la materia prima del dramaturgo, ya que las explicaciones existenciales que persigue Lenormand no residen en la superficie de esta realidad, sino que permanecen ocultas bajo ella. Hay que buscar nuevos instrumentos artísticos -esto es, un nuevo lenguaje teatral-que permitan al escritor sumergirse en el magma del incons- 
ciente, donde radica el verdadero material con el que ha de trabajar el artista moderno. La configuración de este nuevo lenguaje se observa no solo en el mencionado abandono de las leyes temporales y causales. En L'Homme et ses fantômes la unidad psicológica de los personajes también salta por los aires. La personalidad del protagonista de este drama (que carece incluso de un nombre que lo individualice) aparece escindida en diversos personajes: «El Hombre», «El Amigo» y «Luc de Bronte» no son, en el fondo, sino distintas facetas de un solo individuo. La creación de personajes unitarios con una identidad bien definida es sentida por Lenormand como otra de las falsedades del teatro tradicional que han de superarse.

Otra de las razones que explican el interés de la $R O$ en L'Homme et ses fantômes es que, en esta obra, el escritor galo propone una interesante revisión en clave freudiana del personaje de Don Juan, un arquetipo que la Generación del 98 había recuperado a raíz del debate sobre la esencia nacional española y que durante los años veinte había inspirado a numerosos novelistas, dramaturgos y ensayistas españoles ${ }^{8}$. La traducción de este drama de Lenormand en la $R O$ reforzaba la universalidad del personaje de Tirso y respaldaba la defensa que Ortega había hecho del mito de Don Juan como creación arquetípica, pues demostraba que tanto los autores españoles como los dramaturgos extranjeros más celebrados por la crítica y el público seguían teniendo en esta figura del teatro clásico un motivo de inspiración.

Además, El hombre y sus fantasmas revisaba la figura del libertino desde una perspectiva psicológica que interesaba especialmente a los responsables editoriales de la $R O$, y en particular a su director. Ha de tenerse en cuenta que la psicología había despertado un gran interés durante estos años entre los intelectuales españoles, y los colaboradores de la revista no fueron ajenos a esta tendencia. Ortega y Gasset ya había demostrado su inclinación por esta disciplina cuando en 1922 redactó el prólogo para la traducción española de las obras completas de Freud. En este contexto, resulta lógico que de todas

8 Ramiro de Maeztu, en su ensayo Don Quijote, Don Juan y la Celestina, explica así el resurgir del burlador de Sevilla en este periodo: "Don Juan ha vuelto a surgir entre nosotros porque estos años marcan otra crisis de ideales. [...] En esta incertidumbre resurge Don Juan, porque señala la existencia de otra alternativa a cualquier posible elección de ideales, a saber: la factibilidad de vivir sin otro empeño que los vaivenes de nuestros caprichos" (Maeztu, 1999 [1926]: 120-121). Justo Fernández López ofrece una exhaustiva bibliografía sobre "La evolución del tema Don Juan", disponible en versión electrónica en http://hispanoteca.eu/ [fecha de consulta: 6 de mayo de 2017].

9 Sigmund Freud, Obras completas del profesor S. Freud, traducidas directamente del alemán por Luis López-Ballesteros y de Torres. Madrid: Biblioteca Nueva, 1922-1934, 17 vols. Fue concretamente el tomo I -que llevó por título Psicopatología de la vida cotidiana (olvidos, equivocaciones, torpezas, supersticiones y errores) - el prologado por Ortega y Gasset. Acerca de los vínculos que pueden establecerse entre ciertos aspectos de las teorías freudianas y la obra de Ortega, resulta interesante el artículo que García Morente publicó en la Revista de Occidente en septiembre de 1923, en el que enlazaba el paralelismo propuesto por Freud entre chiste e inconsciente, por un 
las obras de Lenormand se escogiera precisamente L'Homme et ses fantômes para ser traducida en la $R O$, ya que se trata de uno de sus dramas más cercanos a las teorías freudianas sobre los sueños. Si los personajes de las obras anteriores relataban en escena lo que soñaban, en este nuevo drama presenciamos unos sueños que se desarrollan ante el espectador siguiendo una lógica totalmente onírica. Estamos, por ello, ante la obra más freudiana de Lenormand.

Con la publicación de El hombre y sus fantasmas, la RO se sumaba, pues, a uno de los debates intelectuales más candentes durante aquellos años: las reinterpretaciones psicológicas del mito de Don Juan. Desde una perspectiva ensayística, el personaje de Tirso había suscitado igualmente el interés de filólogos e historiadores, como Menéndez Pidal (1969 [1906]) o Said Armesto (1968 [1908]). En efecto, desde principios de la década de 1920, fueron muchos los intelectuales de renombre que trascendieron el personaje de Don Juan para analizarlo como uno de los grandes arquetipos que las letras españolas habían ofrecido a la literatura universal (Singer, 1954); de ahí las numerosas publicaciones que, desde esta perspectiva, aparecieron durante la década de los veinte, como las de Ramiro de Maeztu (Don Quijote, Don Juan y la Celestina, 1999 [1926]) o la de Américo Castro (Don Juan en la literatura española, 1924). El propio Ortega y Gasset, en una serie de artículos publicada durante aquellos años en la prensa periódica ${ }^{10}$, reivindicó explícitamente este mito como parte de la esencia española (resulta especialmente interesante su estudio “La estrangulación de Don Juan”, publicado en el diario El Sol el 17 de noviembre de 1935).

La traducción que Enrique Díez-Canedo había realizado de L'Homme et ses fantômes aparecía, pues, en pleno debate sobre el personaje de Tirso, y lo hacía subrayando uno de los aspectos que más controversia había generado: la sexualidad de Don Juan. La obra de Lenormand asumía, al menos en cierto sentido, el tipo de análisis propuesto por Ortega y Gasset. El filósofo español consideraba un error acercarse al mito como si de una persona real se tratase. En su opinión, esta humanización de Don Juan era una de las razones por las que había caído en desgracia: al estudiarlo como una persona de carne y hueso (en lugar de analizar la construcción y los componentes del arquetipo), habían cobrado protagonismo los aspectos más depravados de su conducta, de tal suerte que acabó hacién-

lado, con el vitalismo orteguiano, por otro. Aunque no todos los aspectos de las teorías freudianas convencían a Ortega (López Campillo, 1972), el respaldo de la Revista de Occidente al psicoanalista austriaco, al menos durante los primeros años de la revista, se visualizó de forma aún más evidente en el trabajo de Rodríguez Lafora publicado en el número 16: "Cualquiera que sea la suerte que el porvenir reserve a la obra de Freud, ésta ha sido grandemente fructífera para la concepción moderna de la psicosis y para las múltiples aplicaciones a la criminología, la pedagogía y la sociología” (1924: 165; citado en López Campillo, 1972: 96).

Destaquemos, entre otros trabajos, “Meditación de Don Juan”, El Sol, 21 de junio de 1921. 
dose odioso a ojos de muchos lectores. A pesar de estas advertencias de Ortega, algunos investigadores habían optado por dirigir su mirada precisamente hacia las ataduras más terrenales del personaje: sus impulsos biológicos. Entre estos últimos estudios destaca el de Gregorio Marañón, publicado también en la RO en 1924. El endocrinólogo español, desde una perspectiva médica, dejaba de lado la construcción mítica o literaria de Don Juan y se concentraba en sus conquistas sexuales para explicarlas como resultado de los resortes hormonales.

Al llegar a España en pleno debate intelectual sobre la figura de Don Juan, El hombre y sus fantasmas adquiría unas connotaciones no previstas inicialmente por Lenormand, pues los lectores de la traducción la recibieron como un nuevo eslabón argumental en la ya larga cadena de estudios que se venían sucediendo en el ámbito hispánico desde unos años antes. La traducción del drama de Lenormand, al introducirse en el polisistema literario español, entraba en un diálogo intertextual gracias al cual adquiría nuevas implicaciones. En efecto, los textos traducidos no aparecen por generación espontánea en un vacío, sino que se insertan en un panorama textual preexistente que condiciona la lectura que de ellos hará la sociedad receptora (Even-Zohar, 1979). En otras palabras: la sociedad que asimila los textos extranjeros no es la única que resulta modificada por esta transferencia de obras. También las obras transferidas de un sistema literario a otro sufren una transformación, pues la sociedad receptora no se comporta como un mero contenedor neutro, sino que imprime su propio carácter a las obras recibidas, las cuales se ven así enriquecidas con nuevos matices de los que carecían inicialmente.

Esta es la razón por la que ni siquiera la obra de los autores más «nacionales» —esto es, representativos de la idiosincrasia de cada nación- puede comprenderse cabalmente si la circunscribimos a su territorio nacional. Por el contrario, es necesaria una aproximación supranacional y supralingüística a la literatura universal, pues esta no es la mera suma de las distintas literaturas nacionales, sino una red de influencias generadora de una única literatura plurilingüística. Las distintas corrientes literarias que se han ido sucediendo en Europa a lo largo de su historia nunca se han quedado circunscritas en el territorio en el que han surgido, sino que han atravesado todo tipo de fronteras (geográficas y lingüísticas) para polinizar el resto de sistemas literarios del continente. Y en cada una de estas polinizaciones, además de revigorizar la literatura receptora proporcionándole nuevos temas, géneros literarios, motivos estéticos, etc., estas modas estéticas no han permanecido inalteradas, pues los receptores de estas influencias no se han limitado a copiar mecánicamente los modelos extranjeros recién llegados, sino que han acabado por asumirlos como propios y los han moldeado según su propia tradición literaria. El periodo que estamos estudiando es buena prueba de ello, pues no podríamos estudiar cabalmente el teatro simbolista europeo sin tener en cuenta los continuos contactos que se establecieron entre los diferentes sistemas literarios. Así, el lenguaje expresionista de Lenormand guarda una estrecha relación con las innovaciones es- 
cénicas planteadas por autores como Maeterlinck o Strindbergin, de la misma manera que Lenormand, a su vez, es un claro referente en el expresionismo de autores españoles como, por ejemplo, Jacinto Grau.

En efecto, una buena muestra de este diálogo intertextual que Lenormand estableció con los dramaturgos españoles nos la proporciona Jacinto Grau, quien, el mismo año en que se publicó la traducción española de L’Homme et ses fantômes, escribió una nueva versión del mito de Don Juan (El burlador que no se burla, 1927) en clara reacción a la obra francesa, tal como han señalado diversos críticos (Latcham, 1970; Nougué, 1977; Villagrá Saura, 2003). Antes de conocer el drama de Lenormand, Jacinto Grau ya había publicado una primera versión del clásico (Don Juan de Carillana, 1913) en la que nos mostraba la vejez de Don Juan, pero la lectura de L'Homme et ses fantômes le hizo retomar este personaje en un nuevo drama. Las huellas de la obra de Lenormand en El burlador que no se burla son evidentes; una de las más Ilamativas la encontramos en el quinto cuadro, cuyo título es una clara alusión al autor francés: "Don Juan y los fantasmas". Al igual que Lenormand, Grau apuesta por un lenguaje expresionista y hace aparecer en escena a tres personajes simbólicos que representan sendas pulsiones abstractas («la Vida», «la Muerte» y «el Destino»), proyecciones todas ellas del propio Don Juan. Así se lo hacen saber estas abstracciones al protagonista en unos diálogos de claras resonancias psicoanalíticas: "Figura Negra: Yo no soy yo. Soy solo un signo de tu alma desprendida de ti que no gobiernas ya”. El ego de Don Juan, torturado por la fragmentación de su alma, proyecta sus obsesiones en fantasmas que pueblan su soledad y reflejan sus miedos más profundos.

Las semejanzas entre la obra de Grau y algunos de los diálogos de Lenormand son evidentes y demuestran el protagonismo del autor francés en la difusión de las teorías psicoanalíticas entre algunos dramaturgos españoles de principios de siglo. La influencia de Lenormand resulta especialmente Ilamativa cuando se compara el texto de Grau con las intervenciones del personaje Luc de Bronte, que también explica el comportamiento de Don Juan a partir

11 La influencia de Maeterlinck en el teatro de Lenormand fue percibida por la crítica desde el estreno de sus primeros dramas. Entre las muchas influencias que podrían establecerse entre el autor belga y el francés, se ha destacado la incomunicación en la que ambos autores sumen a sus personajes: estos se limitan a expresar sus sentimientos sin que sus intervenciones guarden relación con las ideas de sus interlocutores. La presencia obsesiva de la muerte y el destino es también otro rasgo del teatro simbolista que comparten sus obras. El propio Lenormand mencionó expresamente a Maeterlinck como la vía a través de la cual le llegaron otras influencias de los grandes dramaturgos escandinavos, como Ibsen o Strindberg: "Maeterlinck m'entraînait dans le sillage brumeux de la cohorte à moitié interdite, à moitié ignorée, des géants du nord" (Lenormand, 1953: 108). Sobre este y otros paralelismos que podrían trazarse entre Lenormand y el teatro escandinavo, cfr. Kaczmarek, 2008: 67-89. 
de la fragmentación de su personalidad y de la proyección de sus temores (citamos por la traducción de Díez-Canedo publicada en la RO):

LUC DE BRonte: [...] Usted que, bajo el nombre de derrota, ha perseguido la soledad, la poblará ahora de apariciones, mientras ella se lo otorgue. Usted, que ha negado el amor y el dolor, afirmará la existencia de puras ilusiones, de imágenes creadas por usted. [...] Los fantasmas acusadores o misericordiosos que se alzan de lo inconsciente, en usted, le preocuparán tanto como sus queridas, créame. Quizás le sea más doloroso deshacerse de ellos. (1927: 341)

Los diálogos de Lenormand adoptan con frecuencia la forma de una sesión con un terapeuta en la que este trata de bucear bajo la superficie de los acontecimientos para penetrar en las profundidades más oscuras del alma. Fragmentos expositivos como el recién citado ilustran bien la tendencia teorizante de Lenormand, que tanto se le ha reprochado por parte de cierta crítica y que podrían explicar, como ya se ha señalado, la falta de sintonía entre el escritor y el público actual. De hecho, algunos de los parlamentos de Luc de Bronte son copias prácticamente literales de las teorías expuestas por el propio escritor en artículos de corte académico. Compárese esta cita extraída de una contribución de Lenormand en el diario Paris-soir con la siguiente intervención de Luc de Bronte al final del cuadro decimotercero de L'Homme et ses fantômes:

Une dissociation interne du moi, un divorce entre les désirs de son corps et ceux de son âme. Le mode d'union que reclame sa chair n'est pas celui auquel il aspire, dans les profondeurs de son inconscient. L'homme qu'il est réclame la femme et la femme qui est en lui et qui s'ignore, réclame l'homme (Paris-soir, 3 de junio de 1924).

Luc de Bronte: En Don Juan el cuerpo es macho y hembra su alma...Su cuerpo pide la mujer y su alma el hombre. Busca en la mujer el fantasma del hombre. Por eso, cada una de sus victorias es una derrota íntima. Por eso huye de las mujeres, en su rabia de encontrarlas ricas de un tesoro que él nunca ha de poseer. Las odia con un odio de mendigo y les inflige sufrimientos que le consuelan de los suyos. Se venga en ellas de su impotencia para la felicidad. Cuando les miente, es a sí mismo a quien intenta engañar (1927: 220).

Quizás una de las razones que explique el olvido en el que han caído las obras de Lenormand sea precisamente su excesiva fidelidad a unas explicaciones psicológicas demasiado ancladas en el espíritu de su tiempo - y a una tendencia a exponerles a los espectadores de forma muy didáctica las razones que explican el comportamiento de los personajes (Ranalli, 1969), lo que convierte algunos de sus dramas en meras "pièces à thèse" (Winnett, 1996: 22)—. Aunque Lenormand rechazó en varias ocasiones estas críticas, no han sido pocos los estudiosos que le han reprochado, pasado el tiempo, que sus dramas parezcan meras ilustraciones de las teorías de Freud. El dramaturgo francés se defendió recurriendo a las fechas de publicación de sus obras: muchos de sus dramas "psicológicos" ya estaban escritos cuando se publicó la 
primera traducción francesa de las obras de Freud, y, dado que no conocía la lengua alemana y no tenía acceso a las versiones originales, cualquier semejanza con el psicoanalista austríaco debería considerarse más como antecedente que como una plasmación teatral de los escritos freudianos ${ }^{12}$.

Los nuevos valores simbólicos que se añadían a L'Homme et ses fantômes al integrarse en el sistema literario español surgían, en cierta medida, de la institución en la que se publicaba, que le transfería a la obra francesa unos valores adicionales: además del prestigio que la $R O$ imprimía a los textos y autores que aparecían en sus páginas, debe recordarse que había sido precisamente en esta revista donde se habían publicado con anterioridad diversas interpretaciones del personaje de Don Juan, como la ya citada de Gregorio Marañón, o los estudios de Ramón Pérez de Ayala (1925) o Ricardo Baeza (1923). El hombre y sus fantasmas entroncaba, pues, con la dimensión sexual abordada por Marañón, pero, en lugar de hacerlo desde una perspectiva biológica, ofrecía ahora un novedoso acercamiento psicológico. Tanto el Don Juan de Marañón como el de Lenormand estaban sujetos a condicionantes que eran incapaces de controlar racionalmente. Ahora bien, mientras que el médico español aspiraba a explicar el comportamiento del seductor a través de las exigencias que le imponía su cuerpo, el dramaturgo francés, más en la línea arquetípica de Ortega, pretendía explicar no las razones de un mujeriego impulsivo, sino el origen del donjuanismo como trastorno psicológico. Esta preferencia de Lenormand por el arquetipo antes que por la persona resulta especialmente visible en la ausencia de nombres para los personajes principales de la obra. El protagonista de la obra de Lenormand recibe únicamente el apelativo de "El Hombre", y algunas de las mujeres que son víctimas de él son nombradas a través de los trastornos psicológicos que padecen por culpa del engaño (este es el caso, por ejemplo, de "La Histérica")³. La aspiración de Lenormand, muy en sintonía con la del propio Ortega, era reflejar a través del protagonista de su obra la desgarrada situación sentimental en la que se encontraba el hombre del siglo XX. Tal como explicó el propio dramaturgo en sus propios comentarios sobre L'Homme et ses fantômes, la angustia del Don Juan moderno no puede comprenderse cabalmente sin atender a las circunstancias históricas que lo envuelven: "L'Homme [...] est, d'abord, une interrogation sur la nature de Don Juan. C'est ensuite un témoignage sur la vie sexuelle de tout homme, [...] II s’agit de donner l'accent de la vérité à la carrière érotique d'un homme de notre temps" (Lenormand, 1942: 276-277; cursivas nuestras).

12 Sobre el acercamiento de Lenormand al psicoanálisis -y particularmente a la persona de Sigmund Freud—, véase Elisabeth Roudinesco, 1986 [1993]: 89-90.

13 Resulta significativo que uno de los pocos personajes con nombre y apellido sea el que hace las veces de psicoanalista: Luc de Bronte, que aparece con este rol en más de una obra de Lenormand. 


\section{Lenormand y el buen gusto}

A las ya dichas, se suma también una razón estilística para explicar el interés que L'Homme et ses fantômes despertó en la RO. Mediante la austeridad formal que le caracteriza (escenas breves y contenidas, frases sencillas, sin adornos, que Díez-Canedo reprodujo en castellano con el literalismo habitual de sus traducciones), Lenormand trataba de impedir una identificación automática entre los espectadores y los personajes de sus obras. Frente al mimetismo en el que se apoyaban otros muchos dramaturgos para conseguir la adhesión del público, Lenormand mantenía al espectador fuera del escenario, para que fuese consciente de que estaba asistiendo a una ficción teatral, a una construcción artística que debía valorar, en consecuencia, con criterios artísticos, no sentimentales. Esta “deshumanización del arte”, por decirlo con las conocidas palabras de Ortega y Gasset, planteaba unos niveles de exigencia que la crítica española destacó en los numerosos artículos publicados en la prensa periódica. Fueron muchos los críticos que, tras elogiar al dramaturgo francés, señalaron que el principal problema al que se enfrentaban sus obras en España era la ausencia de un público preparado para disfrutar de estos planteamientos psicológicos - una razón más para que la RO se fijase en este autor, pues con la traducción de Díez-Canedo la revista contribuía a esa misión pedagógica que había asumido desde su creación-.

Otra de las razones por las que algunos sectores del público español se distanciaron de Lenormand fue su insistencia en los aspectos más escabrosos de la conducta humana. Los impulsos que mueven al hombre proceden de lugares recónditos de su conciencia que tan solo podemos entrever: esta indeterminación sobre los motores que explican las decisiones vitales, sumada a la infelicidad, al hastío y a la tragedia de la existencia, son las notas dominantes en la visión que Lenormand nos ofrece del ser humano a través de su obra, considerada, por ello, un precedente del existencialismo.

El universo onírico que Lenormand conseguía recrear con su teatro simbolista, así como la atmósfera depresiva en la que se desenvolvían sus personajes —incapaces de explicar sus vidas racionalmente - reflejaban bien el ambiente de la sociedad europea de entreguerras; una sociedad incapaz de dominar la evolución de los acontecimientos políticos y económicos del momento, presa de una fatalidad que Lenormand conseguía trasladar fielmente a los escenarios. Los personajes de sus obras “[...] están demasiado cerca de nosotros y tienen todas las taras del hombre de hoy. [...] Dan testimonio de unos tiempos desalentados que, para ser vividos, necesitan considerar como sueño al tiempo mismo", señaló Díez-Canedo en el texto con el que introducía su traducción en la $R O$ (1927: 75-76). Las reflexiones sobre la esencia del ser humano propiciadas por la conmoción que supuso la Primera Guerra Mundial se desarrollaban en un entorno sociopolítico y económico que se encontraba también sumido en su propio proceso de transformación. No era el de Lenormand un teatro agradable de ver para el espectador que solo buscaba un entretenimiento comercial. 
La insistencia en la sexualidad reprimida como uno de los motores del subconsciente otra de las coincidencias más evidentes entre Freud y Lenormand-contribuyó igualmente a que desde ciertos ámbitos sociales se observara con desagrado la llegada a España de los dramas de Lenormand. En las obras del autor francés se explican con frecuencia los trastornos de los personajes a través de sus pulsiones sexuales (la homosexualidad en L'Homme et ses fantômes; el incesto en Le Simoun; el complejo de Edipo en Le Mangeur des rêves; la prostitución en La Maison des Remparts), lo que le valió no pocas críticas por parte de los sectores más conservadores de la sociedad, que no terminaban de aceptar que el artista dirigiese su atención hacia los impulsos más depravados del ser humano.

La crítica española destacó el peso que en la conducta de sus personajes adquirían las pulsiones más inconfesables: “[...] qué sufrimiento, qué carga la del universo de bajeza y corrupción revelado en el fondo del alma, en contraste con la ternura y la abnegación y el genio artístico y la prestancia personal que nacen de tan vil y espeso limo" (Díez-Canedo, 1927: 70). Pero esta insistencia en subrayar los ingredientes más turbios del subconsciente no siempre fue aceptada con la tolerancia que mostró Díez-Canedo en la anterior cita. Si bien algunos críticos continuaban esta misma línea y destacaban el contraste entre "la vileza de carácter" de sus protagonistas y la belleza literaria que Lenormand era capaz de extraer de ellos, no todos, sin embargo, asumieron de buen grado que el autor francés iluminase los rincones más oscuros del alma humana, por lo que fue acusado de atentar contra el decoro (véanse, más adelante, las críticas de José Alsina y Enrique Moreno). No es de extrañar que entre los sectores más conservadores surgiese la indignación al ver sobre los escenarios mujeres que pedían ser humilladas física y verbalmente en sus relaciones sexuales, como sucede en el cuadro séptimo del segundo acto de L'Homme et ses fantômes, cuando el personaje femenino "La Histérica" reconoce con vergüenza su deseo de ser tratada con violencia (1927: 102-103):

La Histérica: Por eso yo... iOh! Es estúpido lo que iba a decir... A mí, que soy una persona más susceptible, me gustaría que usted me tratase duramente. (Inclinada hacia él.) Injurias, groserías, usted puede decírmelas. De antemano le perdono...

\section{$[\ldots]$}

El hombre: (Después de mirarla con desprecio, con una tranquila brutalidad.) ¡Basta de charla! Desnúdese usted. iComo si no supiese usted que antes de cinco minutos estaremos en la misma cama! [...] Los ojos se volverán hacia los demonios interiores, morderá usted, se sofocará como un animal contagiado de hidrofobia... Y pasado un cuarto de hora, esconderá usted de nuevo, bajo palabras hipócritas, su ardor renaciente.

En el quinto cuadro de esta misma obra, el personaje de Laura - una de las mujeres engañadas por el protagonista - nos ofrece una explícita descripción de un aborto ante la que resulta difícil permanecer indiferente: “Toqué no sé qué cosa, decapitada a medias por las 
sondas... ¡Y ante ese cuerpecillo de dedos ya formados, olvidé mi martirio para llorar sobre mi crimen! ¡Le quería, le quería ya! Lo lavé, lo envolví como si fuese a vivir... (Llora.) Yo lo quemé en la chimenea, sobre las brasas... Lo vi consumirse" (1927: 96).

El propio autor, en Les Confessions d'un auteur dramatique, reconocía abiertamente que el propósito que lo había guiado en muchas de sus obras era el de arremeter contra los valores de la burguesía biempensante: "J’ai criblé de flèches le conformisme bourgeois et la morale chrétienne, pour aboutir à une sorte d'immoralisme qui a, lui aussi, son conformisme, ses actions, ses prêtres et qui ressemble à un culte du mal” (1953: 12). Esta voluntad por desenmascarar la hipocresía social desembocó en duras críticas contra la religión, en general, y contra el catolicismo, en particular. Su diatriba contra la Iglesia Católica resulta especialmente visible en Terre de Satan, obra en la que el autor nos presenta al personaje de Lady Sullivan lanzando blasfemias que escandalizaban a no pocos espectadores y lectores: "[...] cet affreux christ, qui a l'air d'un oustiti crucifié".

Ante estos propósitos, no es de extrañar que en una sociedad tan marcada por el catolicismo como la española se plantearan objeciones religiosas a las obras de Lenormand, sobre todo a aquellas como L'Homme et ses fantômes, en las que la sed de trascendencia y espiritualidad no es satisfecha mediante los cauces tradicionales que señalan las instituciones eclesiales, sino a través de propuestas alternativas, como las sesiones espiritistas ${ }^{14}$. Además, la ilustración de las teorías freudianas, al profundizar en los terrenos más oscuros de la conducta, se materializaba en personajes alejados de los principios morales del catolicismo. No fueron pocas las críticas que, al margen de otras consideraciones literarias, se concentraron en la falta de moralidad de los protagonistas de Lenormand. En un artículo anónimo publicado en El defensor de Córdoba el 16 de noviembre de 1928, tras algunas ironías sobre la gran aceptación del autor francés entre el público español (“con acompañamiento de mucha alharaca y mucho ruido de elementos intelectuales han entrado en España Lenormand y su obra”), se puede leer la siguiente crítica:

El fundamento de la derrota [de los personajes de Lenormand] es ese: su fracaso moral. Son seres incompletos, son pobres existencias creadas en el moderno ambiente de la irreligiosidad, de la falta de fe, de la carencia de luz espiritual. Pueden considerarse como símbolos de toda una genera-

14 Tanto en sus dramas como en sus memorias, Lenormand "coquetea" con el ocultismo sin llegar a pronunciarse nunca de forma clara acerca de sus creencias sobre estas prácticas: "In some works, there is an ambiguity about the real force that has ordered the events of the tragedy and the audience is confronted with the possibility of a second interpretation in terms of the occult. This does not always testify to a calculated procedure by Lenormand but rather to the odd mixture of lucidity and mystical inspiration that accompanied the writing of such plays as L'Homme et ses fantômes and L'Amour magicien" (Ranalli, 1969: 70). 
ción moderna: los hombres sin Dios, los pueblos sin fe, las multitudes extraviadas, las inteligencias perdidas entre las tinieblas de escepticismo, los corazones hundidos en el materialismo grosero.

El título del artículo del que extraemos el fragmento citado resulta igualmente significativo: "Lenormand y la fuerza del mal". Esta referencia al mal en los comentarios que juzgaban la obra del dramaturgo francés venía de lejos. Antes de que sus obras se hubiesen estrenado en España, Alberto Insúa, en un artículo publicado tras el estreno en Francia de Le Simoun, insistía también en el comportamiento amoral de muchos de los personajes de este autor, lo que le llevó a establecer ciertos paralelismos entre Lenormand, Baudelaire y Poe (1927: 1). En otro estudio publicado en La Correspondencia de España el 22 de febrero de 1921, Alberto Insúa observaba en Le Simoun "una forma que pudiera llamarse edgapoesca y baudeleriana, porque en ella van unidas la atracción del misterio y del vicio y la voluptuosa elegancia de Las flores del mal. Hay una escena de Le Simoun que no habría podido ser escrita sin la 'Invitation au voyage”".

En algunos casos, sin embargo, la insistencia por parte de la prensa en los aspectos más morbosos de la obra lenormandiana parece que respondía a una estudiada estrategia para atraer espectadores a las salas. Esto es lo que sugiere, por ejemplo, el Ilamativo anuncio publicado en el diario La Voz el 6 de marzo de 1930, en el que, además de informar del estreno de la obra Los fracasados, se lee la siguiente advertencia: "Se advierte al público que se trata de una obra de ambiente y lenguaje realistas no apta para señoritas" (negritas en el original). Antes incluso de que las obras de Lenormand comenzasen a traducirse y estrenarse en España, los críticos de este país ya destacaban en sus crónicas las reacciones que la crudeza del autor francés había provocado entre el público femenino más sensible. José Alsina, en un artículo publicado en La esfera el 16 de agosto de 1924, informó de que en el estreno parisino de L'Homme et ses fantômes algunas señoras tuvieron que abandonar la sala por la impresión que les causó la sesión de espiritismo que se describe en uno de los cuadros de la obra15.

La justicia —entendida como el sentido trascendental para distinguir el bien del males otro de los grandes cimientos de la sociedad que los personajes de Lenormand se atreven a poner en entredicho. En À l'ombre du mal, el personaje de Rougé —despótico colonizador que maltrata a sus subordinados - se muestra escéptico ante los reproches de quienes lo rodean: “La justice? Mais cela n'existe pas, la justice... c'est une idée d’homme, une petite idée

15 Efectivamente, en la sala del Odeón, durante la representación del último cuadro de L’Homme et ses fantômes, algunas mujeres del público abandonaron precipitadamente el teatro cuando hicieron su aparición las actrices disfrazadas de fantasmas. En un decorado siniestro del que se encargó Firmin Gémier, surgieron las actrices maquilladas de forma mortuoria con unas máscaras fluorescentes que contrastaban con la oscuridad amenazante del resto del escenario. 
d’homme, ce n'est pas une réalité" (Lenormand, 1933: 226). Lenormand esboza un panorama ciertamente pesimista de las relaciones sociales: es el mal lo que impulsa a los hombres, y los valores tradicionales en los que se asienta la sociedad no han sido capaces de crear mecanismos para refrenar esta tendencia a la maldad, sino todo lo contrario. La negación hipócrita de la verdadera naturaleza humana ha acabado por potenciar los instintos más bajos del hombre, pues la burguesía conservadora, al negarse a asumir esta maldad implícita, no ha conseguido desarrollar las instituciones necesarias para embridar los impulsos que desembocan en la ley del más fuerte o en una lucha implacable por la supervivencia. La tesis de Lenormand es que solo atreviéndonos a mirar de frente las miserias del alma humana alcanzaremos un conocimiento cabal del hombre. Un asunto bien distinto es adónde habrá de llevarnos este conocimiento más profundo del ser humano. Es este un terreno en el que nuestro dramaturgo no quiere introducirse: "Lenormand a le courage de déceler et de débrider toutes les plaies, mais il reste impuissant à en assainir aucune" (Blanchart, 1947: 230). Alberto Insúa, uno de los críticos españoles que defendió a Lenormand ante las críticas de las que fue objeto, reconocía que el dramaturgo "sorprende al hombre en los instantes agudos de su miseria", y que precisamente por ello "son útiles y saludables las obras patológicas" (1927: 1; cursivas en el original). Ahora bien, continúa Insúa, en los dramas de Lenormand estas miserias se exponen como si fuesen "irremediables"; se trata, en palabras del crítico español, de la actitud propia de los "filósofos cínicos, los inmoralistas, los pesimistas, los conservadores, cuantos no creen en la perfectibilidad o mejoramiento del hombre y sólo se preocupan de vivir, cada cual a su modo, su vida” (op. cit., 1). Casi un siglo después, la crítica contemporánea francesa no ha variado este juicio: "La faillite des valeurs universelles ne débouche pas pour autant, comme chez certains expressionnistes, sur l'aspiration à une humanite régénérée. Le dramaturge est trop individualiste pour s'occuper de masses et trop pessimiste pour croire à la possibilité d'améliorer la condition humaine" (Kaczmarek, 2008: 64). Este relativismo moral que rezumaban los dramas de Lenormand no podía sino provocar rechazo por parte de quienes veían un peligro en el cuestionamiento de la tradición católica española.

\section{Lenormand y la tradición teatral española}

La recepción en España de Lenormand estuvo marcada por la tradicional relación de amorodio con que la sociedad española ha mirado históricamente todo lo proveniente de Francia. Mientras que los sectores más progresistas acogieron afectuosamente sus obras y las asumieron como un modelo capaz de revitalizar el teatro hispano, también hubo quien, una vez más, consideró que las ideas que llegaban de Francia resultaban nocivas. Esta división no solo se manifestó a la hora de valorar la moral que proponía el escritor francés en sus obras. Otro de los debates que Lenormand suscitó entre la crítica española concernía al supuesto carácter renovador de su teatro. Sus innovaciones más visibles afectaban fundamentalmente a la estructura externa de sus dramas, compuestos por breves "cuadros" en los que se repre- 
sentaban distintos momentos de la vida de los personajes. El lector, especialmente el del siglo XXI, educado ya en la ficción cinematográfica, tiene la sensación de estar leyendo el guion de una película antes que una obra de teatro (bastaría con cambiar la terminología del autor y sustituir sus "cuadros" por las actuales "escenas"). Las didascalias, por otra parte, recuerdan en ocasiones a las descripciones de un novelista. No se limitan a dar instrucciones al director o a los actores, sino que introducen reflexiones sobre el comportamiento de los personajes o sus pensamientos. Y entre las instrucciones que conciernen a la descripción del escenario, algunas de ellas parecen pensadas para el rodaje de una película antes que para las limitaciones de una puesta en escena teatral: "Un cafetín en una ancha avenida de la orilla izquierda. [...] Siluetas de transeúntes brotan de vez en cuando de la niebla”, indica el autor al comienzo del cuadro sexto del primer acto de El hombre y sus fantasmas.

Este acercamiento tan cinematográfico a la puesta en escena, así como la rapidez con la que se sucedían los cuadros en las obras de Lenormand suponían una dificultad para el montaje de sus obras. Lo destacó Díez-Canedo en el artículo que publicó en El Sol el 24 de octubre de 1928 a raíz de la representación de Los fracasados en el teatro Fontalba, a cargo de la compañía de Margarita Xirgu. Si bien Díez-Canedo valoraba positivamente la instalación de un escenario móvil que permitía pasar rápidamente de un cuadro a otro, no todos los críticos españoles se mostraron tan elogiosos hacia este rasgo del teatro lenormandiano. Azorín, por ejemplo, también se fijó en este dinamismo escénico, pero se mostró más escéptico a la hora de valorar su carácter innovador. Para Azorín la supuesta novedad que algunos veían en Lenormand no era más que un regreso a “la tradición española” (citado en García Blanco, 2008: 175)

Pese a esta vinculación con la tradición española, la brevedad de estos cuadros y la rapidez con la que avanzaban Ilevaron a algunos críticos a preguntarse si el teatro de Lenormand podría llegar a abrirse paso entre el público español, poco acostumbrado, según ellos, a tanto cambio escénico. De esta opinión participaba, por ejemplo, Enrique Moreno, quien, en un artículo publicado en El avisador numantino el 31 de octubre de 1928, escribió:

Con todo el respeto para el señor Lenormand yo creo que no cuajará su técnica en el teatro español, porque nuestra sensibilidad no es para ese exagerado dinamismo. Será algo nuevo, algo desconcertante, pero nosotros preferimos este teatro nuestro, bello, sereno, rítmico en las escenas, en la forma, en el diálogo, que es arte puro, y que es asequible a todos los públicos, que conmueve al menestral y al burgués, al artista y al profano, y que puede figurar a la cabeza de todos los teatros, como viene figurando desde Tirso y Calderón acá. En Londres triunfan precisamente ahora obras españolas estrenadas aquí hace catorce años.

Al margen de los aspectos estructurales, también los temas propuestos por Lenormand y la perspectiva desde la que los abordaba suscitó intensas reacciones en la prensa española. Entre quienes ponían en duda la modernidad del dramaturgo francés, uno de los argumentos más insistentes consistía en señalar el paralelismo entre sus obras y las tragedias 
clásicas. Lenormand, a juicio de estos críticos, se limitaba a trasladar a un contexto contemporáneo la vieja lucha entre el hombre y su destino, sin introducir ninguna novedad verdaderamente reseñable. Se señalaba que en ambos casos los personajes estaban marcados por una fuerza superior a ellos que los arrastraba inexorablemente al fracaso, cualesquiera que fueran sus propósitos y el empeño en alcanzarlos. A la hora de valorar El hombre y sus fantasmas, la búsqueda de precedentes en el teatro clásico no resultó especialmente ardua, pues, como se ha dicho, se trata de una actualización del mito barroco de Don Juan. En este caso, el rechazo por parte de algunos críticos españoles iba acompañado de un claro componente nacionalista. Al mismo tiempo que se limitaba el alcance de las innovaciones de Lenormand, se realzaba la superioridad de la tradición teatral española, que nada tenía que envidiar a la francesa. Un buen ejemplo de este tipo de valoraciones es la que se publicó, de forma anónima, en El avisador numantino el 31 de octubre de 1928: "[...] en el fondo nada nos ha enseñado este señor Lenormand. El teatro español no tiene que avergonzarse. Podemos enorgullecernos de él. Afortunadamente, nosotros poseemos un teatro que es, desde el venturoso XVI, padre de todos los teatros y no necesitamos del teatro francés ni de las recetas francesas para nada”.

Estas semejanzas entre los dramas de Lenormand y el teatro clásico español fueron objeto de valoraciones bien diferentes por parte de otros sectores de la crítica. En lugar de utilizar este argumento para minusvalorar al autor francés, algunos periodistas lo esgrimieron para resaltar la modernidad del teatro barroco español, capaz de seguir inspirando a los dramaturgos más vanguardistas. De hecho, parte de la crítica siguió la intuición de Azorín ya señalada en páginas anteriores y vio en el dinamismo con el que avanzaban los "cuadros" de Lenormand una influencia del teatro clásico español. Aunque fuese por razones diferentes (en nuestros autores clásicos el cambio de escenario era el resultado de trasladar la acción a otro lugar, mientras que en Lenormand los distintos escenarios reflejaban aspectos diferentes de la personalidad de los personajes), en ambos casos el efecto en el espectador era similar. En una entrevista que concedió al diario $A B C$ el 23 de octubre de 1928, el dramaturgo francés negó cualquier influencia del teatro clásico español sobre sus obras (también rechazó la influencia del teatro renacentista isabelino, con el que le había emparentado la crítica inglesa) y se limitó a señalar que este dinamismo escénico aspiraba tan solo a separarse del teatro francés del XVII, que tanto le desagradaba.

Pese a esta similitud, la diferencia entre la tragedia clásica y el drama psicológico lenormandiano salta a la vista: mientras que en aquella la fatalidad proviene de una fuerza exterior al ser humano, en las obras de Lenormand los personajes están atados a su propio subconsciente, con las implicaciones que de ahí se derivan para la existencia del libre albedrío. Aunque no todos lo vieron así, parte de la prensa teatral española percibió con claridad el deseo de Lenormand de "renovar la tragedia inquiriendo una nueva fatalidad: un fatum científico", en palabras del crítico José Alsina, publicadas en La Esfera el 18 de agosto de 1924. El propio 
autor galo, en una entrevista concedida al diario $A B C$ el 15 de marzo de 1928, insistía en las semejanzas y diferencias entre sus obras y las tragedias clásicas:

Siendo la tendencia del teatro resucitar la tragedia, o por lo menos crear una transposición moderna de la tragedia antigua, es natural que los temas de mis obras sean precisamente aquellos que encontramos en los autores antiguos. Las veleidades incestuosas, o criminales, o destructoras, que minan tan frecuentemente mis personajes, representan el papel de la Fatalidad antigua, pero de una fatalidad interna, de origen psíquico y que únicamente en sus efectos recuerda la maldición de origen divino que aplasta los personajes de los trágicos griegos. Por otra parte, la mayoría de mis obras pretenden ser un testimonio de los tiempos actuales, y es, por lo tanto, inevitable que reflejen la inquietud colectiva, el caos moral y la dispersión del Yo, que son el azote de nuestra época.

La renovación que Lenormand introducía en el teatro clásico fue especialmente señalada en su obra El hombre y sus fantasmas. Mientras que el Don Juan clásico - al menos en algunas de sus muchas versiones - acaba desembocando en la religión, el de Lenormand "orienta su conversión no hacia el dogma cristiano, sino hacia una de esas pseudorreligiones que quieren sustituir a la antigua, esto es, hacia el ocultismo en una de sus formas más elementales, cual la espiritista", le reprochaba el crítico José Alsina en el citado artículo de La Esfera.

Hay otro aspecto de la tradición ensayística sobre Don Juan que Lenormand abandona en su obra. Aunque los condicionantes geográficos constituyeron también una de las vetas que más interés suscitaron entre los estudiosos del personaje clásico, el autor francés marginó este ingrediente en su obra. Ya sea por vincular la pasión amorosa a los cálidos climas del Sur (como parece sugerir Byron en algunos versos de su poema), ya sea por considerarlo un producto característico de la ciudad de Sevilla (como defiende Ortega de forma controvertida en algunos de sus artículos sobre el tema), lo cierto es que, al analizar los ingredientes esenciales del mito de Don Juan, las "razones topográficas" merecieron especial atención para muchos ensayistas (Gil, 2011: 61-62). Fue esta una línea interpretativa de la que, sin embargo, Lenormand se apartó en El hombre y sus fantasmas. Aunque en otros de sus dramas (Le Simoun) el entorno geográfico desempeñó una función esencial y llegó a convertirse, incluso, en un personaje más de la obra, en esta incursión en el donjuanismo dejó al margen las influencias climáticas para concentrarse en las ataduras del subconsciente.

\section{Conclusión}

Ya en 1920, cuando los dramas de Lenormand todavía resultaban desconocidos para el gran público en España, el crítico Alberto Insúa, en las crónicas que enviaba desde París, dudaba del éxito que un teatro tan sombrío como el del dramaturgo francés pudiera tener entre el público español, acostumbrado a unas propuestas teatrales bien diferentes: "No creo que el teatro de M. Lenormand gustase en España. Es un teatro doloroso, un teatro que hace pen- 
sar y sufrir. [...] Por eso digo que ese teatro no gustaría en España, en la España de hoy, que sólo quiere cosquillas" (Correspondencia, 11-VI-1920; citado en Dougherty y Vilches de Frutos, 1990: 45). Sin embargo, una vez que las obras de Lenormand se tradujeron y representaron en Madrid, la acogida del público fue, como se ha dicho, muy favorable, para sorpresa de algunos críticos, quienes destacaron la educación teatral que demostraban los espectadores madrileños al acoger favorablemente las obras de Lenormand. Alejandro Maquis, en un artículo publicado en La Esfera el 3 de noviembre de 1928 después del estreno de Los fracasados, subrayaba la buena recepción que se le había brindado pese al ambiente sombrío en el que transcurría la trama: "La actitud del público ante estas obras ha demostrado que no carece de sensibilidad”. Ahora bien, incluso cuando sus obras eran estrenadas con una gran afluencia de público y satisfacción por parte de este, la crítica más reacia a reconocerle cualquier mérito al dramaturgo galo se mantenía escéptica. Enrique Moreno, por ejemplo, escribió lo siguiente en El avisador numantino el 31 de octubre de 1928:

La noche del estreno, y las sucesivas, aplaudieron todos. Todos. ¿Por qué? Por seguir la corriente. ¿Se enteraron todos? [...] Yo creo que no. No es posible que un público de teatros que no está capacitado para ello asimile a las primeras de cambio una obra de linaje. Estas obras no son para los públicos de teatros de España — ni de ningún país. La cultura del pueblo suele ser deficiente, no pueden penetrar sus inteligencias en estos problemas hondos del pensamiento y del sentimiento. [...] Con ella se aburrirían todos los públicos de teatro de España y se arruinarían todos los empresarios.

Las dudas expresadas en la anterior cita acerca de la capacidad del público español para penetrar en las profundidades psicológicas de Lenormand parecen tener motivaciones extraliterarias. La lectura del resto del artículo del que se ha extraído el fragmento demuestra que lo que realmente molestaba al autor de esas reflexiones eran los aplausos de los espectadores ante una obra que escarbaba en los impulsos más oscuros del ser humano y los mostraba impúdicamente en el escenario. Para ciertos sectores de la crítica, la sociedad española no estaba preparada para digerir las obras de Lenormand, ya fuese por la osadía del autor francés, ya fuese por la incapacidad del público español para apreciar sus innovaciones escénicas; de ahí que se pusiese en duda la sinceridad de los aplausos con los que concluían todos los estrenos del dramaturgo.

Y, sin embargo, este supuesto desfase entre las propuestas estéticas de Lenormand y la sociedad española quedó desmentido por el éxito de sus obras. Las críticas que recibió Lenormand no tenían su origen en unas pretendidas diferencias culturales irreconciliables entre el teatro francés y el español, sino en el desafío que sus dramas lanzaban a los sectores más conservadores de la sociedad. Tal como había sucedido en otros periodos de la historia de España, estos sectores volvían a escudarse en una supuesta especificidad del pueblo español para tratar de impedir la entrada de ideas que circulaban por el resto de Europa. El encono de estos críticos hacia el dramaturgo galo era fruto - hoy lo podemos apreciar con más claridad gracias a la perspectiva que nos otorga la distancia temporal- de la buena acogida que se le 
dispensó en España por parte del público: esta calurosa recepción de la que fue objeto tanto en los teatros como en las revistas culturales resultaba para muchos amenazante, pues ponía de manifiesto que la visión del ser humano que proponía Lenormand podía extenderse con facilidad al sur de los Pirineos, lo cual suponía un riesgo para los valores imperantes en la época. La recepción inicial en España de Henry-René Lenormand ilustra, una vez más, la incapacidad que en ocasiones nos atenaza para trascender los límites de lo propio cuando miramos al Otro. Lo que vemos cuando dirigimos la vista hacia fuera está más condicionado por quiénes somos - o queremos ser- que por las características propias del objeto observado. En el fenómeno de la recepción, son las circunstancias del polo de llegada las que verdaderamente determinan la forma como se acogen las ideas importadas (Toury, 1980).

Unas décadas más tarde, en los años cincuenta, Lenormand volvería a ser representado en Madrid y Barcelona como desafío a la cerrazón cultural —en esta ocasión, del régimen franquista (García Lorenzo, 1999; de Isabel Estrada, 2001)—. En Barcelona, la compañía Teatro de Arte de Marta Grau y Arturo Carbonell representó en 1946 El tiempo es sueño. El grupo teatral Dido, pequeño teatro de cámara de Madrid, montó esta misma obra en 1958 en traducción de Alfonso Sastre. Fue el propio Sastre quien se encargó de redactar el texto que figuraba en el programa de mano. En él se podía leer: "La sociedad en que le tocó vivir [a Lenormand], corrompida, desilusionada, amenazada por la catástrofe, constituyó la materia atestiguada por el dramaturgo, señalado, por este motivo, con el estigma de la corrupción, de la desilusión y del signo catastrófico". Con esta introducción, Sastre no solo estaba contextualizando la obra de Lenormand en el contexto francés de principios de siglo XX, sino que subraya la actualidad del dramaturgo en pleno franquismo. En la década de los cincuenta, cuando este grupo de cámara — dirigido entonces por Josefina Sánchez Pedreño - recuperó a Lenormand, el autor francés seguía suponiendo un desafío para la España conservadora. Téngase en cuenta que la censura solo permitía a este grupo estrenar en representaciones únicas, pues las obras seleccionadas estaban prohibidas en los teatros comerciales (Bloin, 2007) ${ }^{16}$. La desesperación

16 Este ambiente clandestino que rodeaba los estrenos de Lenormand durante el franquismo habría sido muy del gusto del dramaturgo galo, a juzgar por lo que cuenta de él Alfonso Sastre en "Las experiencias de un autor dramático": "[...] en uno de esos periódicos yo había leído un artículo —que todavía lo conservo - que se llamaba "Laboratorios" (Laboratoires) y era de un gran dramaturgo francés, Henri-René Lenormand y hablaba de que en Francia el teatro nuevo, el teatro del futuro, se estaba haciendo no en las salas convencionales de teatro, sino en pequeñas salas donde estaba el espíritu de la novedad, el espíritu de la belleza, etc. y que allí estaría el teatro del futuro. Y que para hacer ese teatro no hacía falta más que tener un pequeño local, vagamente acondicionado porque el drama era el espectáculo de unos seres humanos diciendo unas pasiones, etc. Laboratorio de teatro, se me quedó aquel término. En ese momento de la crisis nuestra en que se produce el reto de que hay que hacer un teatro experimental, es en ese teatro experimental en el que yo pienso, un teatro laboratorio que se había hecho unos años antes en Francia” (2000: 37-38). 
del protagonista de El tiempo es sueño ante la inconsistencia de la realidad que lo rodea no solo admitía un enfoque existencialista, sino también una interpretación de corte más social en la España franquista de los años cincuenta: "Lo terrible es saber que estamos soñando. Caminar y saber que no hay suelo bajo nuestros pasos... pues todo son fantasmas y reflejos de fantasmas", dice Lenormand en boca del protagonista (1960 [1921]: 194).

\section{Bibliografía citada}

Arizmendi Martínez, Milagros, y Mercedes López SuÁrez, 1997: “De la crisis de fin de siglo a las vanguardias" en María del Pilar Palomo (ed.): Movimientos literarios y periodismo en España, Madrid: Síntesis, 279-396.

Baeza, Ricardo, 1923: “Memorias de Jacques Casanova”, Revista de Occidente 6, 364.

BéCARud, Jean, 1972: "Prólogo" en Evelyne López Campillo: La Revista de Occidente y la formación de minorías (1923-1936), Madrid: Taurus, 13-21.

Blanchart, Paul, 1947: Le Théâtre de H.-R. Lenormand. Apocalypse d'une société, Paris: Masques.

BLoın, Barbara, 2007: “Dido, Pequeño Teatro de Madrid i la seva directora Josefina Sánchez Pedreño", Assaign de teatre: Revista de l'associació d'investigació i experimentació teatral 59, 107-116.

Carat, Jacques, 1949: "Confessions d'un auteur dramatique, H.-R. Lenormand", Mémoires et chroniques. Citado en Kaczmarek, 2008, pág. 28.

Cremades Gómez-Pablos, Jacinta, 2003: La España contemporánea en la vida, la obra y la amistad de Jean Cassous. Tesis doctoral, Universidad de Amsterdam [https://pure.uva.nl/ws/files/3646967/26707_Thesis.pdf, fecha de consulta: 29 de abril de 2017].

De Isabel Estrada, María Antonia, 2001: George Bernard Shaw y John Osborne: Recepción y recreación de su teatro en España durante el Franquismo. Tesis doctoral, Universidad Complutense de Madrid [http://biblioteca.ucm.es/tesis/fll/ucm-t28134.pdf, fecha de consulta: 30 de abril de 2017].

Diez-Canedo, Enrique, 1927: "Henri-René Lenormand y el paisaje dramático", Revista de Occidente 49, 64-76.

Dougherty, Dru, y María Francisca Vilches de Frutos, 1990: La escena madrileña entre 1928 y 1926. Análisis y documentación, Madrid: Fundamentos.

Even-Zohar, Itamar, 1979: "Polysystem Theory”, Poetics Today 1 (1-2), 287-310. 
Fusı, Juan Pablo, 2003: La patria lejana, Madrid: Taurus.

Garcia Blanco, Pablo, 2008: Contra la placidez del pantano: teoría, crítica y práctica dramática de Gonzalo Torrente Ballester. Tesis de doctorado, Universidad Carlos III de Madrid.

García Lorenzo, Luciano, 1999: Aproximación al Teatro Español Universitario (TEU), Madrid: Consejo Superior de Investigaciones Científicas.

GIL, Juan, 2011: El burladory sus estragos, Madrid: RAE, discurso leído el 30 de octubre de 2011 por J. Gil con motivo de su ingreso en la RAE [Www.rae.es, fecha de consulta: 25 de noviembre de 2011].

Gravier, Maurice, 1971: "L'Expressionnisme dramatique en France entre les deux guerres" en L'Expressionnisme dans le théâtre européen, colloque organisé par le Centre d’Études Germaniques de l'Université de Strasbourg, Paris: Éditions du CNRS.

InsúA, Alberto, 1927: "En torno a Lenormand”, La Voz, 1.

Kaczmarek, Tomasz, 2004 : "Les ratés de Henri-René Lenormand ou la misère de l'homme sans Dieu”, Acta Universitatis Lodziensis. Folia literaria romanica 3, 129-142.

Kaczmarek, Tomasz, 2008: Henri-René Lenormand et l'expressionnisme dramatique. Tesis doctoral, Universidad de Łódź [http://cejsh.icm.edu.pl/cejsh/element/bwmetal.element. hdl_11089_14465/c/Romanica5_razem.pdf, fecha de consulta: I de mayo de 2017].

Kaczmarek, Tomasz, 2010: "Entre le temps de Kant et le temps d'Einstein, ou requête pour un texte expressionniste français", Études romanes de Brno 31 (2), 47-59.

Kaczmarek, Tomasz, 2015: "Henri-René Lenormand et August Strindberg ou la cruauté du langage, le langage de la cruauté”, Études romanes de Brno 36 (2), 185-195.

LATCHAm, Tomasz, 1970: "El tema de Don Juan y sus derivaciones modernas", Libro de andar y ver (selección, ordenación y notas de Alfonso Calderón y Pedro Lastra), Santiago de Chile: Editorial Andrés Bello, 361-366

Lenormand, Henri, 1925: “Le Théâtre d'avant-garde et ses tendances”, Le Nouveau Journal.

Lenormand, Henri, 1927 [1921]: El hombre y sus fantasmas. Trad. Enrique Díez-Canedo, Revista de Occidente, traducción publicada en los números 49 (77-104), 50 (206-238) y 51 (339-356).

Lenormand, Henri, 1933: Théâtre complet: L'Homme et ses fantômes. À l'ombre du mal, París: G. Crès et cie.

Lenormand, Henri, 1942: "Introduction de L 'Homme et ses fantômes" en S. A. Rhodes (ed.): The contemporary French Theatre. Representative plays, College of the City of New York, Appleton-Century-Croft, 270-277. 
Lenormand, Henri, 1953: Les Confessions d'un auteur dramatique, Paris: Albin Michel.

Lenormand, Henri, 1960 [1921]: El hombre y sus fantasmas. El devorador de sueños. El tiempo es un sueño (2a. edición). Trad. E. Fernández Sanz y José Jiménez, Buenos Aires: Losada.

López Campillo, Evelyne, 1972: La Revista de Occidente y la formación de minorías (1923-1936), Madrid: Taurus.

MaezTu, Ramiro, 1999 [1926]: Don Quijote, Don Juan y la Celestina, Madrid: Visor.

Marañón, Gregorio, 1968 [1924]: "Notas para la biología de Don Juan”, Revista de Occidente 7, 15-53. Citamos por la reimpresión en Obras Completas, Madrid: Espasa-Calpe, 75-93.

Marin Hernández, David, 2011: "Los poemas en prosa de Charles Baudelaire en traducción de Enrique Díez-Canedo" en Francisco Lafarga y Luis Pegenaute (eds.): Cincuenta estudios sobre traducciones españolas, Berna: Peter Lang, 375-388.

Marin Hernández, David, 2013: "La traducción del teatro de vanguardia en las revistas literarias: el Orfeo de Jean Cocteau en la Revista de Occidente" en Emilio Ortega ArJonilla (dir.): Traducir la cultura, Granada: Editorial Comares, 1195-1208.

Martín Rodriguez, Mariano, 1992: "Ejemplos de renovación: teatro francés e italiano en la escena madrileña (1918-1936)" en Dru DougherTY y María Francisca Vilches (eds.): El teatro en España. Entre la tradición y la vanguardia (1918-1939), Madrid: CSIC, 127-135.

Martín Rodriguez, Mariano, 1994: El teatro de lenguas románicas extranjeras en Madrid (19181936). Tesis Doctoral, Universidad Complutense.

Menéndez Pidal, Ramón, 1969 [1906]: "Sobre los orígenes de El convidado de piedra", Cultura Española. Citamos por la reimpresión en Estudios Literarios, Madrid: Espasa-Calpe, 69-88.

MorRISON, Winston G., 1972: The Treatment of the Problem of Evil in the Theatre of Lenormand. Tesis doctoral, Universidad de McMaster [http://digitalcommons.mcmaster.ca/opendissertations/5167, fecha de consulta: 13 de octubre de 2016].

Nougué, André, 1977: “Caracteres del teatro de Jacinto Grau (1877-1958)", Boletín de la institución Fernán González 188, 129-146.

Ortega y Gasset, José, 1990 [1914]: Meditaciones del Quijote, Madrid: Cátedra.

Ortega y Gasset, José, 1961 [1921]: "Introducción a un Don Juan” en Obras Completas, Madrid: Revista de Occidente, vol. 1, 121-137.

Pérez de Ayala, Ramón, 1925: "Sobre las mujeres, el amor y Don Juan", Revista de Occidente 20, $129-245$. 
Ranallı, Gary Richard, 1969: Lenormand et ses fantômes. A Study of the Playwright's work, 19141942. Tesis doctoral, Universidad de McMaster.

Roudinesco, Elisabeth, 1993 [1986]: La Bataille de Cent Ans. Histoire de la psychanalyse en France. Vol. 2, Paris: Seuil. Citamos por la traducción español: La batalla de los cien años. Historia del psicoanálisis en Francia, traducción de Ana Elena Guyer, Madrid: Fundamentos, 1993.

SaId ARmesto, Víctor, 1968 [1908]: La leyenda de Don Juan. Orígenes poéticos de El burlador de Sevilla y convidado de piedra, Madrid: Librería de los sucesores de Hernando, 1908. Citamos por edición de Madrid: Espasa Calpe, 1968.

SAStre, Alfonso, 2000: "Las experiencias de un autor dramático" en Sara M. SAnz (ed.): Retos para un nuevo milenio: lengua, cultura y sociedad. Actas del coloquio internacional AEPE, Colorado State University, 33-48 [http://cvc.cervantes.es/ensenanza/biblioteca_ele/aepe/pdf/coloquio_2000/coloquio_2000_10.pdf, fecha de consulta: 30 de abril de 2017].

Singer, Armand E., 1954: A Bibliography of the Don Juan Theme. Versions and Criticism, West Virginia University Bulletin, Series 54, No. 10-1 [http://www.donjuanarchive.at, fecha de consulta: 29 de octubre de 2016].

Toury, Gideon, 1980: In Search of a Theory of Translation, Tel Aviv: The Porter Institute for Poetics and Semiotics.

Vilches de Frutos, María Francisca, y Dru Dogherty, 1988: "La renovación del teatro español a través de la prensa periódica: La Página Teatral del Heraldo de madrid (1923-1927)", Siglo XX/ 2oth Century 1-2, 47-56.

Vilches de Frutos, María Francisca, y Dru DogherTy, 1997: La escena madrileña entre 1926 y 1931. Un lustro de transición, Madrid: Fundamentos.

Villagra Saura, Katy, 2003: "Don Juan y los fantasmas: un intento de puesta en escena simbolista”, Castilla: Estudios de literatura 28-29, 267-280.

WinnetT, Prudence J., 1996: The expressed and the inexpressible in the theatre of Jean-Jacques Bernard and Henry Rene Lenormand between 1919 and 1945. Tesis doctoral, Universidad de Durham [http://etheses.dur.ac.uk/5102/]. 